\title{
In vitro secretion of FSH by cultured clinically nonfunctioning and gonadotroph pituitary adenomas is directly correlated with locally produced levels of activin $\mathrm{A}$
}

\author{
H. T. Wessels*, L. J. Hofland†, R. van der Walt, \\ L. van Gastel*, P. M. van Koetsveld†, W. W. de \\ Herder† and F. H. de Jong ${ }^{*}, \dagger$ \\ Departments of *Endocrinology \& Reproduction and \\ †Internal Medicine III, Erasmus University Rotterdam, \\ Rotterdam, the Netherlands
}

(Received 8 May; returned for revision 13 June finally revised 24 July 2000; accepted 13 October 2000)

\section{Summary}

OBJECTIVE Expression of mRNAs encoding activin and its antagonists inhibin and follistatin has been described in human pituitary adenomas, including clinically nonfunctioning adenomas (NFAs) and gonadotroph adenomas (Gn-omas). Since many of the NFAs and Gn-omas secrete FSH in vitro, we hypothesized that locally produced activin may stimulate secretion of FSH in these pituitary adenomas.

PATIENTS and METHODS Pituitary adenoma tissue was obtained from 38 patients diagnosed preoperatively as having NFAs $(n=17)$, Gn-omas $(n=5)$, prolactinomas $(n=6)$ or growth hormone (GH)producing adenomas $(n=10)$. Actual protein levels of activin, inhibin, follistatin, FSH and LH were measured in media of these 38 cultured pituitary adenomas. In addition, we investigated correlations between concentrations of these growth factors and hormones in NFAs and Gn-omas.

RESULTS Gn-omas were found to secrete significantly more activin $A$ in their culture medium than PRL- and GH-producing adenomas $(P<0.05)$. Inhibin $A$ and inhibin $B$ protein levels in culture media were very low. A positive correlation between levels of activin $A$ and FSH $(r=0.56, P<0.005)$ was found, while no correlation between activin A and LH could be detected. Furthermore, levels of follistatin were

Correspondence: H.T. Wessels, Erasmus University Rotterdam, Department of Endocrinology \& Reproduction, PO Box 1738, 3000 DR Rotterdam, The Netherlands. Fax: + 31104089461 ; E-mail: hendrika.wessels@uni-essen.de positively correlated with activin A levels $(r=0.73$, $\boldsymbol{P}<\mathbf{0 . 0 0 0 5 )}$. Comparison of the activin A:follistatin ratio with the measured $\mathrm{FSH}$ protein levels showed an even stronger relationship ( $r=0.79, P<0.0005)$.

CONCLUSIONS It is concluded that levels of activin A, follistatin and FSH in media of cultured nonfunctioning adenomas and gonadotroph adenomas are positively correlated. This suggests that these adenomas secrete FSH in response to the relatively high locally produced levels of activin $A$.

Little is known about the aetiology of human gonadotroph pituitary adenomas, except that they are clonal (Snyder, 1985; Alexander et al., 1990). The mutations causing this clonal origin are not known yet, but theoretically, mutations leading to increased activin signalling could be involved. The activins are a group of dimeric peptides (combinations of disulphidelinked inhibin $\beta \mathrm{A}$ and/or $\beta \mathrm{B}$-subunits) produced in a wide variety of tissues including the pituitary gland, which have a diverse range of actions (DePaolo et al., 1991; Ying, 1988). At the pituitary level, activins stimulate $\mathrm{FSH} \beta$ messenger RNA expression and FSH secretion. This action of activin can be blocked by the inhibins (dimeric peptides consisting of the inhibin $\alpha$-subunit, disulphide-linked to either of the $\beta$ - subunits, which are also found in the activins) which antagonize activin by binding to the activin type IIB receptor (Xu et al., 1995; Lebrun \& Vale, 1997; Martens et al., 1997), after interaction with $\beta$-glycan (Lewis et al. 2000). The activin binding protein follistatin is also known to block the action of activin by preventing activin binding to its receptors (Nakamura et al., 1990; Inouye et al., 1991). Alexander et al. (1995) reported the expression of $\beta \mathrm{A}$ and $\beta \mathrm{B}$-subunit mRNA in the normal human pituitary. These authors also found expression of inhibin $\alpha$-subunits in the human pituitary gland. This suggests that both activins and inhibins can be produced by this tissue. Since not only the different subunits, but also follistatin and the activin type I and type II receptors are expressed in the pituitary gland (Kogawa et al., 1991; Alexander et al., 1996), these findings indicate possible autocrine and paracrine roles for activin, follistatin and inhibin in the regulation of FSH secretion. 
Expression of activin/inhibin subunits, follistatin and activin receptor mRNAs has also been described in human pituitary adenomas, including the clinically nonfunctioning adenomas (NFAs) and gonadotroph adenomas (Gn-omas) (Haddad et al., 1994; Alexander et al., 1995; Alexander et al., 1996; Demura et al., 1996; Penabad et al., 1996; Suzuki et al., 1996). Since many of these adenomas secrete FSH in vitro, we hypothesized that locally produced activin may stimulate FSH secretion in NFAs and Gn-omas. To test this hypothesis, we measured actual protein levels of activin, inhibin, follistatin, FSH and LH in media of cultured NFAs and Gn-omas and investigated relationships between concentrations of these growth factors and hormones.

\section{Subjects and methods}

\section{Selection of pituitary adenomas}

Pituitary adenoma tissue was obtained at the time the tissue was excised by transsphenoidal surgery from 38 patients diagnosed preoperatively as having NFAs $(n=17)$, prolactinomas $(n=6)$, Gn-omas $(n=5)$ or growth hormone $(\mathrm{GH})$ producing adenomas $(n=10)$. Patients consented in the studies on the tumour materials. If possible, part of the tissue was frozen in liquid nitrogen and stored at $-80{ }^{\circ} \mathrm{C}$ for extraction of ribonucleic acid (RNA). Gn-omas were defined as pituitary adenomas accompanied by supranormal circulating serum levels of one or both gonadotrophins. NFAs are pituitary tumours which do not cause clinical symptoms of overproduction of pituitary hormones. The NFAs used in this study were 'silent' Gn-omas because of their inability to cause increased peripheral levels of gonadotrophins in vivo despite their ability to synthesize and secrete gonadotrophins in vitro (as reported by Snyder, 1985 and Asa et al., 1986), combined with immunohistochemical evaluation of the adenoma tissues. Table 1 shows the preoperative FSH and LH levels of the patients included in this study together with the coexisting pituitary insufficiencies.

\section{Tissue dispersion and culture of cells}

Adenoma tissue was minced into small pieces and dispersed with dispase (1000 U/l), erythrocytes were removed by centrifugation on a Ficoll gradient and tumour cells were plated into 48-well plastic culture dishes (Costar, Cambridge, USA) in MEM/Dval (Life Technologies, Paisley, Scotland) containing $10 \%(\mathrm{v} / \mathrm{v})$ foetal calf serum and penicillin/streptomycin as described previously (Oosterom et al., 1984). The dishes were maintained at $37{ }^{\circ} \mathrm{C}$ under humidified air containing $5 \%$ carbon dioxide for at least $72 \mathrm{~h}$ to allow cell attachment. After renewal of the media and a further $72 \mathrm{~h}$ incubation period the media were collected and stored at $-20^{\circ} \mathrm{C}$ until assayed for activin $\mathrm{A}$, inhibin $\mathrm{A}$, inhibin $\mathrm{B}$, follistatin, FSH and $\mathrm{LH}$.

\section{Assays}

Total dimeric inhibin A and B, activin A and follistatin were measured in the conditioned media using commercially available two-site enzyme-linked immunoassays (Serotec Ltd, Oxford, UK; School of Biological \& Molecular Sciences, Oxford Brookes University, Oxford, UK). Cross-reactivity between inhibin $\mathrm{A}$ and inhibin $\mathrm{B}$ is $<0.5 \%$ (LambertMesserlian et al., 1994). Cross-reactivities of inhibin A, inhibin B and follistatin in the activin A assay are $0.5 \%$, $0.4 \%$ and $<0.1 \%$, respectively (Knight et al., 1996). Within and between assay coefficients of variation $(\mathrm{CVs})$ were below 8 and $14 \%$ for these assays. Detection limits for the activin A-, inhibin A-, and inhibin B-assays were $10 \mathrm{ng} / \mathrm{l}$, for the follistatin-assay $19 \mathrm{ng} / \mathrm{l}$.

FSH and LH were measured using Amerlite kits, supplied by Orange-Clinical Diagnostics, Amersham, UK, or using the Immulite System (Diagnostic Products Corporation, Los Angeles, CA, USA). Within and between assays, CVs were below 3 and $8 \%$ for FSH and 5 and $15 \%$ for $\mathrm{LH}$, respectively.

All hormone levels were corrected for cell number and expressed per 100000 cells.

\section{Extraction of RNA}

Frozen tumour tissue was pulverized using an ultra-turrax (IKA Werk, Staufen, Germany) and total RNA was isolated using TRIzol reagent (Life Technologies, Breda, the Netherlands) according to the manufacturer's instructions. After isolation, the RNA was dissolved in RNase free water. Concentration and integrity of total RNA were determined by measuring optical densities at 260 and $280 \mathrm{~nm}$.

\section{Reverse transcription $(R T)$ and polymerase chain reaction $(P C R)$}

Complementary DNA was synthesized from $2.5 \mu \mathrm{g}$ of total RNA from seven NFAs by a random hexamer-primed reverse transcriptase reaction (Van Schaik et al., 1997). Parallel samples without added reverse transcriptase were also subjected to this treatment in order to exclude amplification of genomic DNA. The reversely transcribed product of each pituitary extract was amplified for inhibin $\alpha-, \beta A$ - and $\beta$ B-subunits, activin type I receptors, activin type II receptors, follistatin, pit-1 and $\beta$-actin. Human placenta DNA was included as a positive control, water was used as a negative control. Table 2 shows the synthetic oligonucleotides used (Pharmacia Biotech, Woerden, the Netherlands). $1.5 \mu$ RT-product was incubated 
Table 1 Preoperative serum FSH and LH levels of patients included in the study

\begin{tabular}{|c|c|c|c|c|c|}
\hline Type of adenoma & Sex & $\begin{array}{c}\text { Age at operation } \\
\text { (years) }\end{array}$ & $\begin{array}{c}\text { Serum } \\
\text { FSH (IU/l) }\end{array}$ & $\begin{array}{c}\text { Serum } \\
\text { LH (IU/l) }\end{array}$ & $\begin{array}{c}\text { (Co-existing) } \\
\text { pituitary insufficiencies }\end{array}$ \\
\hline NFA \#1 & Female & 72 & 1.4 & 0 & (G)/A/T/GH \\
\hline NFA \#2 & Male & 67 & $7 \cdot 2$ & 1.9 & $\mathrm{G} / \mathrm{A} / \mathrm{T} / \mathrm{GH}$ \\
\hline NFA \#3 & Male & 65 & $0 \cdot 5$ & 0 & $\mathrm{G} / \mathrm{A} / \mathrm{T} / \mathrm{GH}$ \\
\hline NFA \#4 & Male & 65 & $2 \cdot 0$ & $0 \cdot 6$ & $\mathrm{G} / \mathrm{A} / \mathrm{T} / \mathrm{GH}$ \\
\hline NFA \#5 & Female & 64 & $6 \cdot 9$ & $1 \cdot 1$ & (G)/A/T/GH \\
\hline NFA \#6 & Male & 66 & $7 \cdot 9$ & $3 \cdot 4$ & - \\
\hline NFA \#7 & Female & 49 & $0 \cdot 5$ & $1 \cdot 3$ & $\mathrm{G} / \mathrm{A} / \mathrm{T} / \mathrm{GH}$ \\
\hline NFA \#8 & Male & 56 & $3 \cdot 3$ & $1 \cdot 7$ & $\mathrm{G} / \mathrm{A} / \mathrm{T} / \mathrm{GH}$ \\
\hline NFA \#9 & Female & 76 & $1 \cdot 3$ & 0 & (G)/A/T/GH \\
\hline NFA \#10 & Male & 70 & $1 \cdot 5$ & $0 \cdot 4$ & $\mathrm{G} / \mathrm{A} / \mathrm{T} / \mathrm{GH}$ \\
\hline NFA \#11 & Male & 64 & $1 \cdot 1$ & $1 \cdot 3$ & $\mathrm{G} / \mathrm{A} / \mathrm{T} / \mathrm{GH}$ \\
\hline NFA \#12 & Male & 57 & n.d. & n.d. & $\mathrm{G} / \mathrm{A} / \mathrm{T} / \mathrm{GH}$ \\
\hline NFA \#13 & Male & 59 & n.d. & n.d. & G/A/T/GH \\
\hline NFA \#14 & Male & 46 & $8 \cdot 8$ & $0 \cdot 4$ & $\mathrm{G} / \mathrm{A} / \mathrm{T} / \mathrm{GH}$ \\
\hline NFA \#15 & Female & 60 & $26 \cdot 9$ & $10 \cdot 8$ & (G) \\
\hline NFA \#16 & Male & 60 & $2 \cdot 3$ & $0 \cdot 9$ & $\mathrm{G} / \mathrm{A} / \mathrm{GH}$ \\
\hline NFA \#17 & Female & 37 & n.d. & n.d. & $\mathrm{G} / \mathrm{A} / \mathrm{T} / \mathrm{GH}$ \\
\hline Gn-oma \#1 & Male & 60 & $30 \cdot 3$ & $0 \cdot 6$ & G/T/GH \\
\hline Gn-oma \#2 & Female & 32 & $28 \cdot 4$ & $10 \cdot 5$ & $\mathrm{G}$ \\
\hline Gn-oma \#3 & Male & 49 & $19 \cdot 0$ & $2 \cdot 6$ & n.d. \\
\hline Gn-oma \#4 & Female & 74 & $34 \cdot 3$ & $1 \cdot 4$ & (G) \\
\hline Gn-oma \#5 & Male & 59 & $20 \cdot 1$ & $0 \cdot 9$ & $\mathrm{G} / \mathrm{A} / \mathrm{T} / \mathrm{GH}$ \\
\hline PRL-producing adenoma \#1 & Female & 58 & $2 \cdot 6$ & 0 & $\mathrm{G}$ \\
\hline PRL-producing adenoma \#2 & Male & 41 & $0 \cdot 5$ & 0 & $\mathrm{G} / \mathrm{A} / \mathrm{T} / \mathrm{GH}$ \\
\hline PRL-producing adenoma \#3 & Female & 27 & $0 \cdot 7$ & $0 \cdot 2$ & $\mathrm{G}$ \\
\hline PRL-producing adenoma \#4 & Female & 21 & $4 \cdot 2$ & $16 \cdot 6$ & $\mathrm{G}$ \\
\hline PRL-producing adenoma \#5 & Male & 22 & $1 \cdot 1$ & 0 & $\mathrm{G} / \mathrm{A} / \mathrm{T} / \mathrm{GH}$ \\
\hline PRL-producing adenoma \#6 & Female & 45 & $0 \cdot 8$ & $0 \cdot 1$ & $\mathrm{G}$ \\
\hline GH-producing adenoma \#1 & Male & 26 & $3 \cdot 4$ & $0 \cdot 8$ & - \\
\hline GH-producing adenoma \#2 & Male & 32 & $3 \cdot 9$ & $1 \cdot 1$ & - \\
\hline GH-producing adenoma \#3 & Female & 53 & n.d. & n.d. & (G) \\
\hline GH-producing adenoma \#4 & Female & 52 & $57 \cdot 2$ & $25 \cdot 2$ & (G) \\
\hline GH-producing adenoma \#5 & Male & 57 & $5 \cdot 3$ & $3 \cdot 4$ & - \\
\hline GH-producing adenoma \#6 & Male & 46 & n.d. & n.d. & - \\
\hline GH-producing adenoma \#7 & Male & 34 & $1 \cdot 0$ & 0 & $\mathrm{G} / \mathrm{A} / \mathrm{T}$ \\
\hline GH-producing adenoma \#8 & Male & 40 & $3 \cdot 1$ & $2 \cdot 8$ & - \\
\hline GH-producing adenoma \#9 & Male & 49 & $1 \cdot 7$ & $0 \cdot 5$ & - \\
\hline GH-producing adenoma \#10 & Male & 57 & $3 \cdot 2$ & 1.7 & - \\
\hline
\end{tabular}

n.d. not done; G, gonadal insufficiencies; (G), postmenopausal gonadal insufficiencies; A, adrenal insufficiencies; T, thyroid insufficiencies; GH, IGF-I levels significantly decreased.

Normal FSH levels: men 2-7 IU/l; women 1-7 IU/1 (postmenopausal women 35-150 IU/l). Normal LH levels: men 1.5-8 IU/l; women 1-8 IU/1 (postmenopausal women 15-90 IU/l).

with 25 pmol of each pair of specific $5^{\prime}$ and $3^{\prime}$ oligonucleotide primers in the presence of $0.5 \mathrm{mM}$ of each of the four deoxyNTPs (Boehringer Mannheim GmbH, Mannheim, Germany), 0.25 U Super Taq DNA polymerase (HT Biotechnology Ltd, Camebridge, UK), $10 \mathrm{mM}$ Tris-HCl, $\mathrm{pH} 9.0,1.5 \mathrm{mM} \mathrm{MgCl}_{2}$, $500 \mathrm{mM} \mathrm{KCl}, 0 \cdot 1 \%$ Triton $\mathrm{X}-100$ and $0.01 \%$ (w/v) gelatin. PCR-reactions were performed in a Perkin-Elmer/Cetus thermal cycler (Norwalk, CT, USA). The amplification profile was divided in denaturation at $95{ }^{\circ} \mathrm{C}$ for 1 minute, annealing at
$55{ }^{\circ} \mathrm{C}$ for 2 minutes and extension at $72{ }^{\circ} \mathrm{C}$ for 2 minutes. The 40 cycles were preceded by a denaturation at $95{ }^{\circ} \mathrm{C}$ for 5 minutes and immediately followed by a final extension at $72{ }^{\circ} \mathrm{C}$ for 10 minutes The PCR products were electrophoresed on a $1.5 \%$ agarose gel, stained with ethidium bromide and visualized under ultraviolet light. PCR products were transferred to nylon membrane filters, and Southern hybridization was performed with ${ }^{32} \mathrm{P}$-labelled full length cDNA probes at $42{ }^{\circ} \mathrm{C}$ for minimal $2 \mathrm{~h}$. After washing with SSC/SDS buffers at 
Table 2 Oligonucleotide primers used for RT-PCR amplification

\begin{tabular}{|c|c|c|c|}
\hline cDNA & Forward primer $\left(5^{\prime} 3^{\prime}\right)$ & Reverse primer $\left(5^{\prime} 3^{\prime}\right)$ & Reference \\
\hline Inhibin $\alpha$ subunit & cgaattctagcagggccaggtgagct & tgtaagcttgtggctgggaaaaggat & (Mason, 1994) \\
\hline Inhibin $\beta A$ subunit & cgagacagggaagacatgccagg & ggatgctgctggagacaggg & (Mason et al., 1986) \\
\hline Inhibin $\beta B$ subunit & cgaattcatcagcttcgecgagac & tgtaaagcttgcactgtcaggcgcagccgc & Patent US seq14: I01852 \\
\hline ALK2 (ActRIA) & gagtatggcactatcgaagggct & gaagatcttcacggcaacatttt & (Ten Dijke et al., 1994) \\
\hline ALK4 (ActRIB) & atcgacttgagggtgccc & gaatattttcacagccacatcac & (Ten Dijke et al., 1994) \\
\hline ActRIIA & cagggaactggatatctagagagaacttc & tggtcctgggtctcgagtaggaacaagtac & (Donaldson et al., 1992) \\
\hline ActRIIB & cgaattccgctgctgcccattggaggc & tgtaagcttgtggccetcaccacgacacc & (Attisano et al., 1992; Hilden et al., 1994) \\
\hline Follistatin & cgaattcttttccacccccac & tgtaagcttctctcctactcccaaacccc & (Shimasaki et al., 1989) \\
\hline Pit-1 & agtgctgccgagtgtctacca & tttctttcctttcatttgct & (Tatsumi et al., 1992) \\
\hline$\beta-\operatorname{actin}$ & aagaattcctatgtgggcgacgag & tagaagcttttgcggtggacgatggag & (Ponte et al., 1984) \\
\hline
\end{tabular}

$42{ }^{\circ} \mathrm{C}$, autoradiography was performed at $-80{ }^{\circ} \mathrm{C}$ with Fuji Medical X-ray films (Fuji Photofilm co Ltd, Tokyo, Japan).

\section{Statistical analysis}

Statistical analysis for comparison of data from more than two groups, was performed using one-way analysis of variance (ANOVA) on logarithmically transformed data; concentrations below the limit of detection were assumed to be equal to this limit in order to make the transformation possible. This was followed by Tukey's test. $P$-values smaller than 0.05 were considered to indicate statistical significance. Correlation coefficients were determined using linear regression analysis, again after logarithmic transformation of the data.

\section{Results}

\section{Expression of inhibin subunit and activin receptor mRNAs in pituitary adenoma tissue}

Using RT/PCR in combination with southern hybridization, we screened seven NFAs for the expression of the inhibin subunits and activin type I and type II receptors. The tumours expressed specific mRNAs for the inhibin $\alpha$-subunit (seven of the seven), the inhibin $\beta A$-subunit (seven of the seven), and the inhibin $\beta B$-subunit (one of the seven) (Table 3). All adenomas expressed ALK2 (activin type IA receptor, ActRIA) mRNA. ALK4 (activin type IB receptor, ActRIB) mRNA was detected in three, whereas ActRIIA-and ActRIIB-mRNA was detected in four and two of the NFAs, respectively. All tissues were positive for $\beta$-actin and negative for pit-1. Since pit-1 is normally found in somatotroph, lactotroph and thyrotroph cells, but not in gonadotroph cells (Asa et al., 1993; Friend et al., 1993), the absence of pit-1 in NFAs indicates the absence of normal pituitary tissue contaminating the adenomas.

\section{Levels of activin $A$, inhibin $A$ and inhibin $B$ in medium of cultured pituitary adenomas}

Activin A protein levels were measured in media of six cultured PRL-producing adenomas, $10 \mathrm{GH}$-producing adenomas, five Gn-omas and 17 NFAs (Fig. 1). Activin A concentrations in culture medium from Gn-omas were significantly higher than in culture medium collected from PRL-and GH-producing adenomas $(P<0 \cdot 05)$. No significant difference was observed between the amount of activin A secreted by Gn-omas and NFAs. Inhibin A levels were undetectable in all of the tested

Table 3 RT-PCR results of inhibin subunit-, follistatin- and activin receptor-mRNAs and activin A levels in media of cultured cells of seven NFAs. n.d. not done

\begin{tabular}{|c|c|c|c|c|c|c|c|c|c|c|c|}
\hline Pat.nr & $\beta$-actin & pit-1 & $\alpha$ & $\beta A$ & $\beta B$ & Alk2 & Alk4 & ActRIIA & ActRIIB & folli-statin & Act.A $(\mu \mathrm{g} / 1)$ \\
\hline$\# 10$ & + & - & + & + & - & + & - & - & - & + & 0.04 \\
\hline \#11 & + & - & + & + & - & + & - & - & - & - & 0.04 \\
\hline \#13 & + & - & + & + & - & + & - & + & + & + & $5 \cdot 18$ \\
\hline$\# 14$ & + & - & + & + & - & + & + & + & - & - & 0.53 \\
\hline \#16 & + & - & + & + & + & + & + & + & - & + & 0.54 \\
\hline \#18 & + & - & + & + & - & + & + & + & + & + & n.d. \\
\hline \#19 & + & - & + & + & - & + & - & - & - & - & n.d. \\
\hline
\end{tabular}




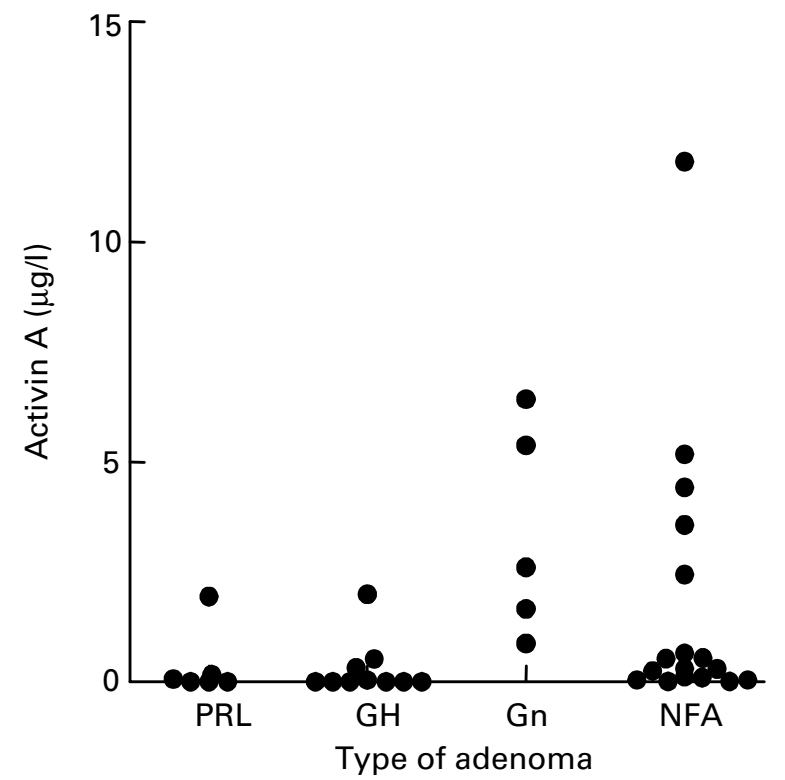

Fig. 1 Activin A protein levels in media of cultured pituitary adenomas. PRL, prolactin producing adenomas $(n=6)$; GH, Growth hormone-producing adenomas $(n=10)$; Gn, Gn-omas $(n=5)$; NFA, clinically nonfunctioning adenomas $(n=17)$. Values are expressed per $10^{5}$ cells.

adenomas, except for one, while inhibin B levels were all very low or undetectable (data not shown).

\section{Activin A, follistatin and gonadotrophins in media of gonadotroph adenomas in vitro}

Activin A and FSH levels in the media of five cultured Gnomas and 17 cultured NFAs were positively correlated ( $r=0.56, P<0.005$, Fig. 2). No significant correlations were observed between activin A-and LH-protein levels $(r=0 \cdot 31)$ and between FSH and LH protein levels in the media of the cultured adenomas ( $r=0.35$; data not shown). Furthermore, FSH levels in preoperative serum samples and culture media of the tested adenomas were positively correlated ( $r=0.58, P<0.005$, Fig. 3 ).

All of the 16 tested adenomas secreted follistatin into the culture medium. A positive correlation was observed between activin $\mathrm{A}$ and follistatin in the media of the gonadotroph and non-functioning adenomas in vitro $(r=0.73, P<0.0005$, Fig. 4). Finally, since levels of free activin (i.e. the activin which is not bound to follistatin), rather than the total concentration of activin, are important for the regulation of FSH secretion, we calculated activin:follistatin ratios in the media of the different adenomas. Comparison of the activin:follistatin ratio with the measured FSH levels revealed a positive correlation $(r=0.79, P<0.0005$, Fig. 5).

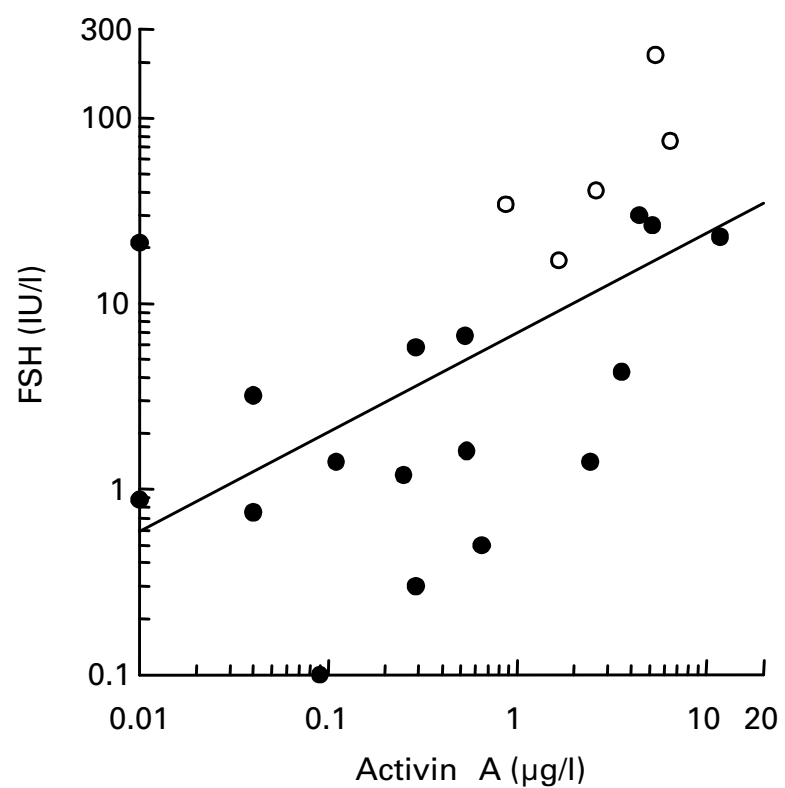

Fig. 2 Correlation between activin A- and FSH-protein levels in media of cultured Gn-omas $(\mathrm{O}, n=5)$ and cultured NFAs $(\bullet, n=17)$. $r=0.56, P<0 \cdot 005$. Values are expressed per $10^{5}$ cells.

\section{Discussion}

The results of the RT-PCR studies on the presence of the $\alpha$ - and $\beta A$-subunit mRNA expression confirm and extend the results

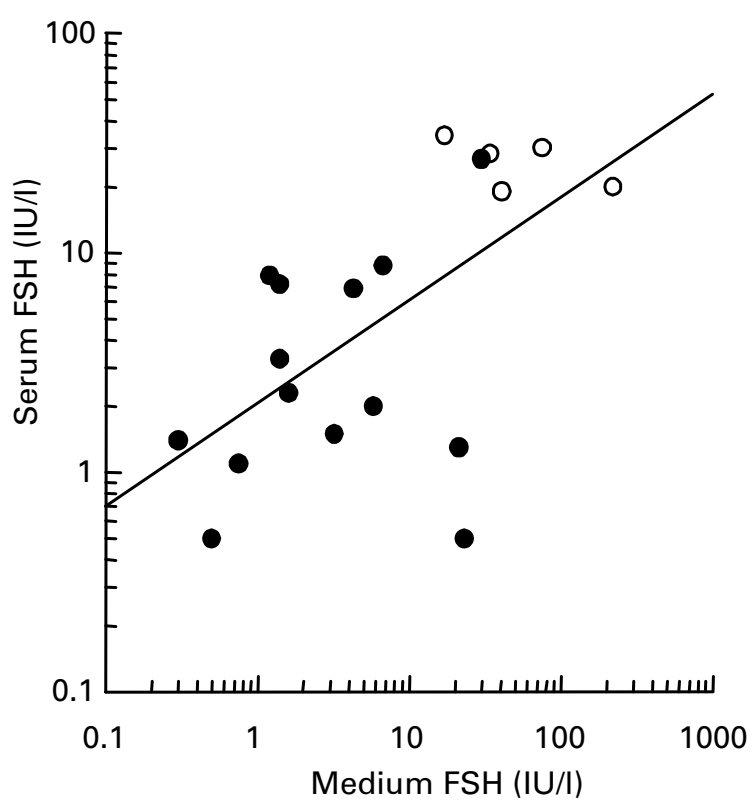

Fig. 3 Correlation between FSH levels in media of cultured Gn-omas $(\mathrm{O}, n=4)$ and cultured NFAs $(\bullet, n=14)$ and in preoperative sera of patients. $r=0.58, P<0 \cdot 01$. Values are expressed per $10^{5}$ cells. 


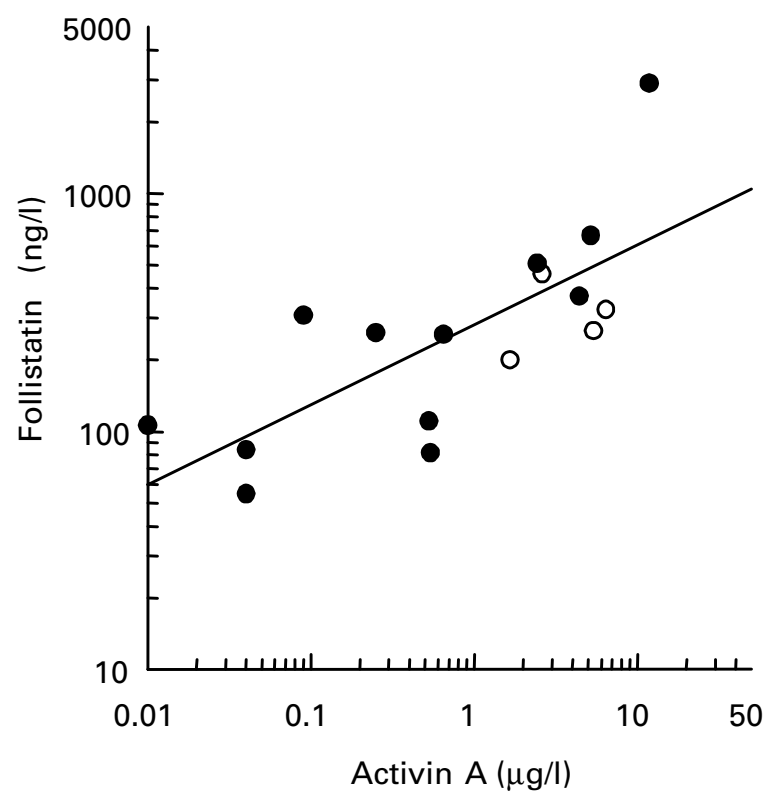

Fig. 4 Activin A vs. follistatin protein levels in media of cultured Gn-omas $(\mathrm{O}, n=4)$ and cultured NFAs $(\bullet, n=12) . r=0 \cdot 73$, $P<0.005$. Values are expressed per $10^{5}$ cells.

of earlier studies in which expression of inhibin subunit mRNAs in human pituitary adenomas has been described (Haddad et al., 1994; Alexander et al., 1995; Suzuki et al., 1996). This indicates, that these adenomas in principle are able

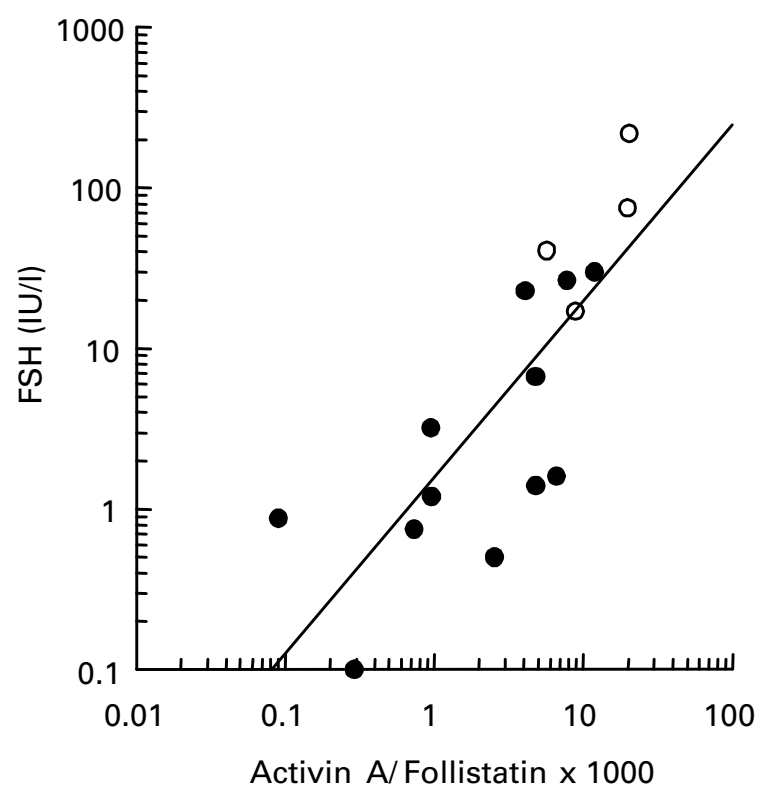

Fig. 5 Activin A:Follistatin-ratio vs. FSH protein levels in media of cultured Gn-omas $(\bigcirc, n=4)$ and cultured NFAs $(\bullet, n=12)$. $r=0.79, P<0.0005$. Values are expressed per $10^{5}$ cells. to produce inhibin A and activin A. Only one out of seven tested NFAs expressed $\beta B$ mRNA, suggesting that, in general, inhibin $\mathrm{B}$ and/or activin $\mathrm{B}$ do not play a major role in the autocrine regulation of FSH-secretion by NFAs. ALK2 mRNA encoding one of the possible activin type I receptors in the pituitary, was present in all of the tested NFAs. This contrasts with findings from Alexander et al. (1996) who could not detect ALK2 mRNA in nine tested NFAs. ALK4 mRNA was detected in three out seven NFAs indicating that this type I receptor can only play a limited role in the pathogenesis of NFAs. The fact that mRNAs encoding activin type II receptors (ActRIIA and ActRIIB) were detected only in NFAs which secrete relatively large amounts of activin A, may suggest a positive relationship between the amount of activin A produced by NFAs and the expression of the activin type II receptors by these adenomas.

To our knowledge this is the first study in which actual protein levels of activin A in media of cultured pituitary adenomas have been measured. We have shown that Gn-omas release significantly more activin A into the culture medium than prolactinomas and GH-producing adenomas. In NFAs and Gn-omas in vitro, a positive correlation was found between activin A and FSH secretion, suggesting an autocrine action of activin A in these tumours. These results are in accordance with recently published data (D'Abronzo et al., 1999), describing no activating mutations in activin type I receptors in FSH secreting tumours. The positive correlation between FSH levels in media of the cultured adenomas and FSH levels in sera of the patients, indicates that our culture system reflects the in vivo situation as far as FSH secretion is involved. As expected, no correlations between activin $\mathrm{A}$ and $\mathrm{LH}$ were found. Inhibin A and inhibin B protein levels were low, indicating that there is too little local inhibin production to affect FSH secretion despite readily detectable expression of $\alpha$-subunit mRNA. A recent report (Borgato et al., 1998) also described the lack of correlation between inhibin A and FSH production in Gn-omas. Although we suggest a possible autocrine role for activin $\mathrm{A}$ in the pathogenesis of Gn-omas and NFAs, recently published data indicate an antiproliferative effect of activin in five out of 16 tested NFAs (Danila et al. 2000).

The presence of mRNA encoding the activin-binding protein follistatin has been described in normal human pituitary and human pituitary adenomas (Alexander et al., 1996; Penabad et al., 1996). Our study shows a positive correlation between activin A-and follistatin-protein levels in media of cultured NFAs and Gn-omas, suggesting that activin A can stimulate follistatin production by these adenomas. Similar effects of exogenously added activin on follistatin mRNA expression have been described in cultured rat anterior pituitary cells (Bilezikjian et al., 1996). However, follistatin levels in NFAs 
and Gn-omas were apparently not high enough to suppress the effect of activin A on FSH secretion completely, although the relationship between FSH secretion and the activin/follistatin ratio was stronger than that between FSH and activin. These findings contrast with the findings of Penabad (Penabad et al., 1996) who used semiquantitative RT-PCR to show that expression of follistatin mRNA in pit-1-negative gonadotroph adenomas is lower than in nonadenomatous gonadotroph cells and concluded that decreased follistatin expression in gonadotroph adenomas leads to an enhanced effect of activin which would account for increased cell division and FSH secretion. This indicates again that mRNA levels do not necessarily correlate with protein production.

In summary, our data show that there are positive correlations between the concentrations of activin A, follistatin and FSH secreted by nonfunctioning adenomas and gonadotroph adenomas in vitro. These results suggest that the production of activin A might be the reason for the relatively high levels of FSH and follistatin in the media of these cultured adenomas. However, the amount of follistatin apparently is not sufficient to antagonize the stimulatory effect of activin A on FSH secretion.

\section{Acknowledgements}

These studies were supported in part by a grant from the European Commission. The authors wish to thank Dr J.H. van de Berge, Dr A. Dallenga, Dr E.J. Delwel and the nursing staff of the operation rooms for supplying them with the adenoma tissue.

\section{References}

Alexander, J.M., Bikkal, H.A., Zervas, N.T., Laws, E.R. Jr \& Klibanski, A. (1996) Tumor-specific expression and alternate splicing of messenger ribonucleic acid encoding activin/transforming growth factor- $\beta$ receptors in human pituitary adenomas. Journal of Clinical Endocrinology and Metabolism, 81, 783-790.

Alexander, J.M., Biller, B.M., Bikkal, H., Zervas, N.T., Arnold, A. \& Klibanski, A. (1990) Clinically nonfunctioning pituitary tumors are monoclonal in origin. Journal of Clinical Investigation, 86, 336 340.

Alexander, J.M., Swearingen, B., Tindall, G.T. \& Klibanski, A. (1995) Human pituitary adenomas express endogenous inhibin subunit and follistatin messenger ribonucleic acids. Journal of Clinical Endocrinology and Metabolism, 80, 147-152.

Asa, S.L., Gerrie, B.M., Singer, W., Horvath, E., Kovacs, K. \& Smyth, H.S. (1986) Gonadotropin secretion in vitro by human pituitary null cell adenomas and oncocytomas. Journal of Clinical Endocrinology and Metabolism, 62, 1011-1109.

Asa, S.L., Puy, L.A., Lew, A.M., Sundmark, V.C. \& Elsholtz, H.P. (1993) Cell type-specific expression of the pituitary transcription activator pit-1 in the human pituitary and pituitary adenomas. Journal of Clinical Endocrinology and Metabolism, 77, 1275-1280.
Attisano, L., Wrana, J.L., Cheifetz, S. \& Massague, J. (1992) Novel activin receptors: distinct genes and alternative mRNA splicing generate a repertoire of serine/threonine kinase receptors. Cell, $\mathbf{6 8}$, 97-108.

Bilezikjian, L.M., Corrigan, A.Z., Blount, A.L. \& Vale, W.W. (1996) Pituitary follistatin and inhibin subunit messenger ribonucleic acid levels are differentially regulated by local and hormonal factors. Endocrinology, 137, 4277-4284.

Borgato, S., Persani, L., Romoli, R., Cortelazzi, D., Spada, A. \& BeckPeccoz, P. (1998) Serum FSH bioactivity and inhibin levels in patients with gonadotropin secreting and nonfunctioning pituitary adenomas. Journal of Endocrinological Investigation, 21, 372-379.

D’Abronzo, F.H., Swearingen, B., Klibanski, A. \& Alexander, J.M. (1999) Mutational analysis of activin/transforming growth factor- $\beta$ type I and type II receptor kinases in human pituitary tumors. Journal of Clinical Endocrinology and Metabolism, 84, 1716-1721.

Danila, D.C., Inder, W.J., Zhang, X., Alexander, J.M., Swearingen, B., Hedley-Whyte, E.T. \& Klibanski, A. (2000) Activin effects on neoplastic proliferation of human pituitary tumors. Journal of Clinical Endocrinology and Metabolism, 85, 1009-1015.

Demura, R., Kubo, O., Suzuki, T., Yajima, R., Tajima, S., Takakura, K., Demura, H., Aiba, M. \& Eto, Y. (1996) Demonstration of activin in normal pituitary and in various human pituitary adenomas by immunohistochemistry. Endocrine Journal, 43, 429-432.

DePaolo, L.V., Bicsak, T.A., Erickson, G.F., Shimasaki, S. \& Ling, N. (1991) Follistatin and activin: a potential intrinsic regulatory system within diverse tissues. Proceedings of the Society of Experimental Biology and Medicine, 198, 500-512.

Donaldson, C.J., Mathews, L.S. \& Vale, W.W. (1992) Molecular cloning and binding properties of the human type II activin receptor. Biochemical and Biophysical Research Communications, 184, 310316.

Friend, K.E., Chiou, Y.K., Laws, E.R. Jr, Lopes, M.B. \& Shupnik, M.A. (1993) Pit-1 messenger ribonucleic acid is differentially expressed in human pituitary adenomas. Journal of Clinical Endocrinology and Metabolism, 77, 1281-1286.

Haddad, G., Penabad, J.L., Bashey, H.M., Asa, S.L., Gennarelli, T.A., Cirullo, R. \& Snyder, P.J. (1994) Expression of activin/inhibin subunit messenger ribonucleic acids by gonadotroph adenomas. Journal of Clinical Endocrinology and Metabolism, 79, 1399-1403.

Hilden, K., Tuuri, T., Eramaa, M. \& Ritvos, O. (1994) Expression of type II activin receptor genes during differentiation of human K562 cells and cDNA cloning of the human type IIB activin receptor. Blood, 83, 2163-2170.

Inouye, S., Guo, Y., Ling, N. \& Shimasaki, S. (1991) Site-specific mutagenesis of human follistatin. Biochemical and Biophysical Research Communications, 179, 352-358.

Knight, P.G., Muttukrishna, S. \& Groome, N.P. (1996) Development and application of a two-site enzyme immunoassay for the determination of 'total' activin-A concentrations in serum and follicular fluid. Journal of Endocrinology, 148, 267-279.

Kogawa, K., Nakamura, T., Sugino, K., Takio, K., Titani, K. \& Sugino, H. (1991) Activin-binding protein is present in pituitary. Endocrinology, 128, 1434-1440.

Lambert-Messerlian, G.M., Hall, J.E., Sluss, P.M., Taylor, A.E., Martin, K.A., Groome, N.P., Crowley, W.F. Jr \& Schneyer, A.L. (1994) Relatively low levels of dimeric inhibin circulate in men and women with polycystic ovarian syndrome using a specific two-site enzyme- linked immunosorbent assay. Journal of Clinical Endocrinology and Metabolism, 79, 45-50.

Lebrun, J.J. \& Vale, W.W. (1997) Activin and inhibin have 
antagonistic effects on ligand-dependent heteromerization of the type I and type II activin receptors and human erythroid differentiation. Molecular and Cellular Biology, 17, 1682-1691.

Lewis, K.A., Gray, P.C., Blount, A.L., MacConell, L.A., Wiater, E., Bilezikjian, L.M. \& Vale, W. (2000) Betaglycan binds inhibin and can mediate functional antagonism of activin signalling. Nature, 404, 411-414.

Martens, J.W., de Winter, J.P., Timmerman, M.A., McLuskey, A., van Schaik, R.H.M., Themmen, A.P.N. \& de Jong, F.H. (1997) Inhibin interferes with activin signaling at the level of the activin receptor complex in Chinese hamster ovary cells. Endocrinology, 138, 2928 2936.

Mason, A.J. (1994) Functional analysis of the cysteine residues of activin A. Molecular Endocrinology, 8, 325-332.

Mason, A.J., Niall, H.D. \& Seeburg, P.H. (1986) Structure of two human ovarian inhibins. Biochemical and Biophysical Research Communications, 135, 957-964.

Nakamura, T., Takio, K., Eto, Y., Shibai, H., Titani, K. \& Sugino, H. (1990) Activin-binding protein from rat ovary is follistatin. Science, 247, 836-838.

Oosterom, R., Blaauw, G., Singh, R., Verleun, T. \& Lamberts, S.W.J. (1984) Isolation of large numbers of dispersed human pituitary adenoma cells obtained by aspiration. Journal of Endocrinological Investigation, 7, 307-311.

Penabad, J.L., Bashey, H.M., Asa, S.L., Haddad, G., David, K.D., Herbst, A.B., Gennarelli, T.A., Kaiser, U.B., Chin, W.W. \& Snyder, P.J. (1996) Decreased follistatin gene expression in gonadotroph adenomas. Journal of Clinical Endocrinology and Metabolism, 81, 3397-3403.

Ponte, P., Ng, S.Y., Engel, J., Gunning, P. \& Kedes, L. (1984) Evolutionary conservation in the untranslated regions of actin mRNAs:
DNA sequence of a human beta-actin cDNA. Nucleic Acids Reserach, 12, 1687-1696.

Shimasaki, S., Koga, M., Buscaglia, M.L., Simmons, D.M., Bicsak, T.A. \& Ling, N. (1989) Follistatin gene expression in the ovary and extragonadal tissues. Molecular Endocrinology, 3, 651-659.

Snyder, P.J. (1985) Gonadotroph cell adenomas of the pituitary. Endocrine Reviews, 6, 552-563.

Suzuki, T., Demura, R., Yajima, R., Tajima, S., Kubo, O., Yoshimoto, T. \& Demura, H. (1996) Inhibin $\alpha, \beta A$ and $\beta B$ subunit messenger ribonucleic acids expression in human pituitary adenomas: studies by quantitative reverse transcription-polymerase chain reaction. Endocrine Journal, 43, 353-356.

Tatsumi, K., Notomi, T., Amino, N. \& Miyai, K. (1992) Nucleotide sequence of the complementary DNA for human Pit-1/GHF-1. Biochimica et Biophysica Acta, 1129, 231-234.

Ten Dijke, P., Yamashita, H., Ichijo, H., Franzen, P., Laiho, M., Miyazono, K. \& Heldin, C.H. (1994) Characterization of type I receptors for transforming growth factor- $\beta$ and activin. Science, 264, 101-104.

Van Schaik, R.H.M., Wierikx, C.D.J., Looijenga, L.H.J., Oosterhuis, J.W. \& de Jong, F.H. (1997) Human testicular germ cell tumours express inhibin subunits, activin receptors and follistatin mRNAs. British Journal of Cancer, 76, 1191-1198.

Xu, J., McKeehan, K., Matsuzaki, K. \& McKeehan, W.L. (1995) Inhibin antagonizes inhibition of liver cell growth by activin by a dominant-negative mechanism. Journal of Biological Chemistry, 270, 6308-6313.

Ying, S.Y. (1988) Inhibins, activins, and follistatins: gonadal proteins modulating the secretion of follicle-stimulating hormone. Endocrine Reviews, 9, 267-293. 